\title{
PATEN RIGHTS OF MITO PRODUCTS
}

\author{
M.Rian Safei \\ 155100045 \\ Fakultas Komputer, 448757153 \\ m.riansafei.student@umitra.ac.id
}

\begin{abstract}
A number of achievements have been achieved by MITO Mobile (The Most Favorite, Best Seller Mobile, The Most Innovative Phone) and are partners of some of the largest telecommunications operators in Indonesia. Various types of mobile phones have been released by MITO Mobile, always being innovative, stylish, high-tech products at affordable prices for the people of Indonesia.

In addition to relying on product quality, Mito Mobile seriously improves after-sales service with service centers spread in almost all cities in Indonesia, until now Mito Mobile is one of the largest local mobile phones in Indonesia with a wide distribution channel. Currently, Mito Mobile has a Service Centers / After-Sales Services that are spread throughout most of Indonesia and with a strong vision to be the best in Indonesia, Mito is always present by offering quality, high-tech, innovative products at affordable prices.

Mito is the brand that has the smallest opportunity to maintain its consumer, which is $0 \%$ and is a brand that has the greatest chance of losing consumers so that in the coming period Mito has the smallest market share of $0.7 \%$. The equilibrium period occurs in the 24th period.
\end{abstract}

Keywords: Cash Receipts and Expenditures. 


\section{A. INTRODUCTION}

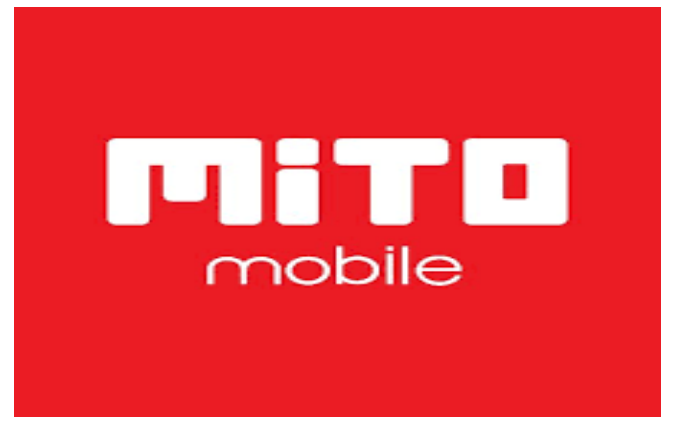

MITO Mobile was one of the pioneers of the first local 2006vendor in Indonesia since. Entering the end of 2012, MITO Mobile managed to become the Top 3 largest mobile vendor in Indonesia with a growing market share and distribution channels that were evenly distributed throughout Indonesia. In addition to relying on product quality, Mito Mobile seriously improves after-sales service with service centers that are spread in almost all cities in Indonesia. Until now Mito Mobile is one of the largest local mobile phones in Indonesia with a wide distribution channel. "Various types of mobile phones have been released by MITO Mobile, always being an innovative product, stylish, high-tech at an affordable price for the people of Indonesia", said Hansen Lie (Managing Director of Mito Mobile) At present, Mito Mobile has Service Centers / After-Sales Services that are spread throughout almost all of Indonesia. And with a strong vision to be the best in Indonesia, Mito is always present by offering quality, high-tech, innovative products at affordable prices. Local smartphone company Mito Mobile is preparing for the construction of its own cellphone factory. The construction of a factory in the Tangerang area, Banten has a production capacity of approximately 1 million units per month. "Our factory is ready now with an investment of around Rp300 billion," said Hansen Lie, Mito Mobile's Marketing Director. And that is no less important is the construction of a factory will open new jobs for the best sons and daughters of the nation, "he said. Currently, said Hansen, the company is awaiting government policy regarding the import of spare parts. It is hoped that by owning a cellphone factory, Mito's progress will be more aggressive by releasing quality, competitive, unique products in accordance with segmentation. On the other hand Mito also released a lot of cellphones with good specifications so that they can be relied upon in processing applications with fairly high graphics. Like Mito Fantasy X A17, the latest mobile phone series from Mito comes with a 4.5 inch LCD screen that has a 720 pixel HD resolution. With this type of screen, Mito Fantasy X A17 is able to display images clearly enough. In addition, Mito Fantasy X A17 is also equipped with two camera lenses, each of which has a resolution of $2 \mathrm{Mp}$ for the front camera and $5 \mathrm{Mp}$ for the rear camera, with these two camera lenses, of course you will be easier to capture the moments. (Picture of Mito Fantasy XA17)

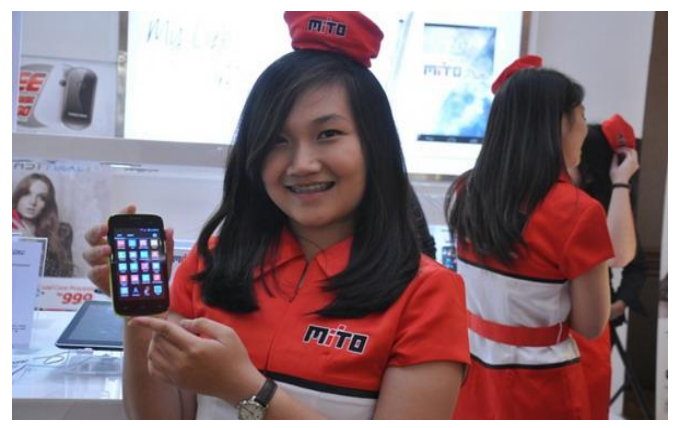




\section{B. CONCLUSION}

The conclusion is one of the pioneers of the first local vendor in Indonesia since 2006 and Entering the end of 2012, MITO Mobile has succeeded in becoming the Top 3 largest mobile vendor in Indonesia with a growing market share and distribution channels that are evenly distributed throughout Indonesia.

Local smartphone company Mito Mobile is preparing for the construction of its own cellphone factory. The construction of a factory in the Tangerang area, Banten has a production capacity of approximately 1 million units per month. And the importance of building a factory will open new jobs for the best sons and daughters of the nation, the company is awaiting government policy regarding the import of spare parts. It is hoped that by owning a cellphone factory, Mito's progress will be more aggressive by releasing quality, competitive, unique products in accordance with segmentation.

Various types of mobile phones have been released by MITO Mobile, always being innovative, stylish, hightech products at affordable prices for the people of Indonesia.

\section{ACKNOWLEDGEMENT University Of Indonesia University Of Mitra Indonesia Telkom University University Of Mellbourne Saitama University}

\section{REFERENCE (Based ISO 690 )}

A. S. Putra And O. M. Febriani,
"Knowledge Management
Online Application In Pdam
Lampung Province," In
Prosiding rernational
Conference On Information
Technology And Business
(Icitb), 2018, Pp. 181-187.

A. S. Putra, O. M. Febriani, And B. Bachry, "Implementasi Genetic Fuzzy System Untuk Mengidentifikasi Hasil Curian Kendaraan Bermotor Di Polda Lampung," J. Sist. Inf. Dan Manaj. Basis Data, Vol. 1, No. 1, Pp. 21-30, 2018.

[3] O. M. Febriani And A. S. Putra, "Sistem Informasi Monitoring Inventori Barang Pada Balai Riset Standardisasi Industri Bandar Lampung," J. Inform., Vol. 13, No. 1, Pp. 90-98, 2014.

[4] Putra, Arie Setya. "2018 Artikel Struktur Data, Audit Dan Jaringan Komputer." (2018).

[5] Putra, A. S. (2018, July 17). Paperplain Fundamental Create Application With Borland Delphi 7.0 University Of Mitra Indonesia. Retrieved From Osf.Io/Pbrn9. 


\section{E. REFERENCE $($ Based APA)}

Putra, A. S., Aryanti, D. R., \& Hartati, I. (2018, November). Metode SAW (Simple Additive Weighting) sebagai Sistem Pendukung Keputusan Guru Berprestasi (Studi Kasus: SMK Global Surya). In Prosiding Seminar Nasional Darmajaya (Vol. 1, No. 1, pp. 85-97).

Sari, D. P., Febriani, O. M., \& Putra, A. S. (2018, November). Perancangan Sistem Informasi SDM Berprestasi pada SD Global Surya. In Prosiding Seminar Nasional Darmajaya (Vol. 1, No. 1, pp. 289-294).

Putra, A. S. (2018). Paperplain: Execution Fundamental Create Application With Borland Delphi 7.0 University Of Mitra Indonesia.

Putra, A. S., Sukri, H., \& Zuhri, K. Sistem Monitoring Realtime Jaringan Irigasi Desa (JIDES) Dengan Konsep Jaringan Sensor Nirkabel. IJEIS (Indonesian Journal of Electronics and Instrumentation Systems), 8(2), 221232.

Darmawan, A., Yuliawati, D., Marcella, O., \& Firmandala, R. (2016). Sistem Absensi dan Pelaporan Berbasis Fingerprint dan SMS Gateway. EXPLORE, 7(1).

Febriani, O. M., Wahyuni, T., \& Yusuf, S. (2017). DESIGN OF WEBSITE-BASED INFORMATION SYSTEM FOR EDOCUMENT ADMINISTRASI IN THE COMMUNITY SERVICE UNIT (A Case Study at Rajabasa District). INTERNATIONAL JOURNAL OF
COMPUTERS \& TECHNOLOGY, 16(7), 7010-7020.

Febriani, O. M., \& Wahyuni, T. (2017, October). PERANCANGAN SISTEM E-DOCUMENT ADMINISTRASI LOGBOOK PENELITIAN PADA UNIT LAYANAN DI BANDAR LAMPUNG. In Prosiding Seminar Nasional Darmajaya (Vol. 1, No. 1, pp. 187-194).

Febriani, O. M., \& Permadi, A. B. (2017). Implementasi Sistem Aplikasi Data Bimbingan dan Pelanggaran Siswa pada Sekolah Menengah Atas di Lampung Tengah dengan Metode Analisis dan Desain Sistem Terdistribusi (SSAD). EXPERT, 7(1).

Febriani, O. M., \& Ambarwati, L. (2015). PERANCANGAN APLIKASI PENGOLAHAN DATA PENJUALAN UKM KELANTING KHAS TELO DESA SIDOHARJO KECAMATAN JATI AGUNG KABUPATEN LAMPUNG SELATAN. Jurnal Teknologi Informasi dan Bisnis Pengabdian Masyarakat Darmajaya, 1(1), 77-95.

Febriani, O. M. (2015). Rancang Bangun Aplikasi Ecommercemenggunakan Freewebstore pada UKM Kelanting di Desa Sidoharjo Lampung Selatan. Prosiding Sembistek 2014, 1(02), 446-458. 